\title{
PHARMACODYNAMICS STUDY OF ETHANOL EXTRACT OF Cyclea barbata (Miers.) LEAVES ON SRF AND COX-2 GASTRIC MICE WITH NSAID GASTROPATHY
}

\author{
Florence Pribadi*, Suhartati, Achmad Basori
}

Faculty of Pharmacy, Universitas Airlangga, Prof. Dr. Moestopo no 47, Surabaya, Indonesia

Submitted: $18-03-2017$

Revised: 09-05-2017

Accepted: $03-07-2017$

*Corresponding author

Florence Pribadi

Email:

florence.pribadi@ciputra.ac.id

\begin{abstract}
Epidemiology of NSAIDs gastropathy is increasing as increase number of usage. From arthritis to cardiovascular events and cancer prevention, the versatility of NSAIDs is not questioned. However, no dose of NSAIDs is safe. No matter low dose, or single use, NSAIDs will cause gastric damage upto 3-7 days after use. In inflammation and healing process of gastropathy there were various proteins involved, but treatment with COX-2 and SRF were associated with an immediate healing and better quality of gastric mucosa. Cyclea barbata (miers.) has been declared as a functional food for preventing and treatment gastropathy yet, its mechanism of actions have not yet clearly discovered. Hence the aim of this study is to analyze the effects of Cyclea barbata (miers.) ethanol extract to COX-2 and SRF in gastric tissue, in time series basis. Laboratory mice were induced with aspirin to produce gastropathy and then treated with Cyclea barbata (miers.) extract for 1, 3, 7, 10 or 14 days. Gastric tissue then harvested and analysed with elisa procedure to determine tissue SRF and COX-2 level. Treatment was proven to increase COX-2 and SRF higher than the control group. This concludes one of Cyclea barbata (miers.) mechanism for NSAIDs gastropathy is by increasing tissue COX-2 and SRF.
\end{abstract}

Keywords: Aspirin-induced gastropathy, COX-2, SRF, NSAIDs

\section{INTRODUCTION}

Aspirin though well known for its gastrointestinal side effects, remains the most common used drug. Many prevention and treatment options were available for aspirin induced gastropathy (Brown et al., 2006; Melcarne et al., 2016). Natural remedies have been researched and proven to have protective and therapeutic effects due to their active ingredients, i.e polyphenols and flavonoids (Farzaei et al., 2015; Simon and Evan 2017).

Natural remedy commonly used is Cyclea barbata (miers.) leaves. It has been used across south east Asia region as refreshing drinks and natural remedies for stomachache and fever dated since the 1980s (Trimurtini 2015; Verpoorte et al., 1982). Further researches of Cyclea barbata (miers.) shown several properties ie: antibacterial (Permanasari, 2015), antioxidant (Shodiq Ali Muhammad, 2012), anticancer (Alam et al., 2016) and an effective therapy for NSAID induced peptic ulcer that is as leaast equal to misoprostol (Trimurtini,
2007). Those properties were gained from their active contents, namely: polyphenol, tannin, flavonoid, (DL)-proto-quersitol, bis-benzylisoquinoline alkaloid, calcium, phosphor, vitamin A and B (Permanasari, 2015).

Ingestion of flavonoids through diet or as pure compounds can be trace in the gastrointestinal tract for a period of time, hence considered as first putative target of flavonoid. Flavonoids effect on gastric mucosa involves blockade of acid secretion, direct prostaglandin E2-dependent and antioxidative action by chelating ROS. Flavonoids may also reduce intestinal motility and secretion to reducing chronic inflammatory injury (Samara, 2009).

COX-2 is the culprit of many inflammation disease and understood that inhibiting COX-2 would bring healing, sadly that is a giant misconception. As COX-2 is the one stimulate growth factor production and epithelial proliferation that were important in ulcer healing (Tarnawski, 2012). 
Serum Response Factor (SRF) is a transcription factor that plays equally important roles in healing and the cell phenotypic modulator. SRF acts as a central regulator of genes involved in apoptosis, dedifferentiation, proliferation, and migration of cells (Ro and Words 2016). Gastric injury activates SRF expression in the epithelial cells lining ulcer margin and regenerating glands; and in myofibroblasts and smooth muscle cells of granulation tissue (Chai, 2004). Healing process involves four main processes ie homeostasis, inflammation, proliferation and glands reconstruction, COX-2 is involved in inflammation and SRF is involved in all four. This study interest is in finding the role of Cyclea barbata (miers.) extract in the healing process of NSAIDs gastropathy and an effort to establish a time line of COX-2 and SRF gastric tissue concentration.

\section{MATERIAL AND METHOD \\ Extract Preparation}

Three $\mathrm{kg}$ of Cyclea barbata (miers.) leaves harvested on January 2017 (Kediri area). Fresh leaves were washed and dried with open air for about 1 week. The extraction procedure was done in Materia medica, Batu. The procedures were grounding dried leaves and sifting with $0.125 \mathrm{~mm}$ sifter resulting $300 \mathrm{~g}$ fine powder. Powder mixed with $3000 \mathrm{~mL} 70 \%$ ethanol $(1: 10)$ and macerated for 5 days in room temperature and thickened with a rotary evaporator in $50^{\circ} \mathrm{C}$ resulting final product of $195 \mathrm{~mL}$ of thick extract. Extract then diluted with distilled water to get $50 \mathrm{mg} / \mathrm{mL}$ solution.

\section{Polyphenol content determination}

The procedure was done in Testing Unit, Faculty of Pharmacy, University of Airlangga. Results show polyphenol in extract was $1.14 \pm 0.02 \% \mathrm{~B} / \mathrm{B}$

\section{Animals}

40 male laboratory mouse (Mus musculus) strain Balb/c were used, obtained from the center of veterinary pharmacy Surabaya, the weight range of $25-35 \mathrm{~g}$, placed under controlled conditions (room temperature kept $28-32^{\circ} \mathrm{C}$, and $12-12 \mathrm{~h}$ light-dark cycle). Diet and water provided ad libitum. Experimental procedures were approved by the Health Research Ethical Clearance Commision (HRECC) from Faculty of Dentistry Univeristy of Airlangga.

\section{NSAIDs gastropathy induction procedure}

Aspirin (Bayer) diluted with distilled water to make a solution of $50 \mathrm{mg} / \mathrm{mL}$. All animals were fasted from food for $24 \mathrm{~h}$ before induction by oral gavage $2 \times 200 \mathrm{mg} / \mathrm{kg}$ BW for 1 day. After induction, animals were randomly divided into 10 groups of 4 mouse.

\section{Research procedure}

Groups of the mouse were number K1-K10. Groups were paired by two K1-K2 (treatment for 1 day), K3-K4 (treatment 3 days), K5-K6 (treatment for 7 days), K7-K8 (treatment for 10 days), K9-K10 (treatment for 14 days). Odd groups were control group receiving distilled water and even numbered group were treatment, receiving once a day $40.5 \mathrm{mg} / \mathrm{kg}$ BW Cyclea barbata (miers.) ethanol extract.

After completed treatment, subjects were fasted for $12 \mathrm{~h}$ and terminated, the abdomen was opened, stomach organ located, cut open along the greater curvature and cleaned with phosphate buffer solution $\mathrm{pH}$ 7.4. After general examination for hemorrhage and ulcer, tissue harvested were prepared for elisa procedure in Leprosy laboratory in Tropical Disease Centre, University of Airlangga, with COX-2 and SRF kit (bioassay).

\section{RESULTS AND DISCUSSION}

The results of COX-2 and SRF were shown (Table I and II) respectively. In day 1, there is no diffrence between control and treatment groups, might be because treatment has not interfered COX-2 nor SRF synthesis.

Table I. Gastric tissue COX-2 (ng/mL)

\begin{tabular}{lccl}
\hline Day & Control & Treatment & P-value \\
\hline 1 & 0.0220 & 0.02825 & 0.08976 \\
3 & 0.0728 & 0.04675 & 0.01327 \\
7 & 0.0690 & 0.1045 & 0.00086 \\
10 & 0.0605 & 0.0625 & 0.7282 \\
14 & 0.0523 & 0.05475 & 0.3911 \\
\hline
\end{tabular}


Table II. Gastric tissue SRF (ng/L)

\begin{tabular}{ccll}
\hline Day & Control & Treatment & P value \\
\hline 1 & 0.0220 & 0.02825 & 0.8376 \\
3 & 0.0728 & 0.04675 & 0.04311 \\
7 & 0.0690 & 0.1045 & 0.01187 \\
10 & 0.0605 & 0.0625 & 0.1047 \\
14 & 0.0523 & 0.05475 & 0.00051 \\
\hline
\end{tabular}

\section{cox-2}

On day 3, control group has higher results than treatment, this proves that one time induction of NSAIDS can cause gastropathy stimulating the production of tissue COX-2 and keep progressing until day 3-7 (Soylu et al., 2008). Treatment group COX-2 on this day is lower than control might be due to Cyclea barbata (miers.) ROS chelating effect and activate gastroprotection (Lucena Périco et al., 2015), hence delay gastropathy progression and causing delayed in COX-2 concentration peak up to day 7 . This research also shows that in day 7 , treatment group has 30\% higher results than control and 100\% increase from treatment group from day 3 . This surge shows that active chemical content from the ethanol extract of Cyclea barbata (miers.) does have gastroprotective activity, and improve healing, hence can be said have a therapeutic effect in gastropathy.

COX-2 in both groups was shown increasing tough aspirin is an irreversible and unselective COX inhibitor. Therefore can be concluded increasing amount of COX-2 is by newly synthetized. Day 10 marks the start of proliferation stage of wound healing (Wietecha, 2015). Both control and treatment group experience decreasing the level of COX-2 on day 10 and 14 suggesting no more stimuli to provoke inflammation in the gastric area, suggesting acute inflammation is over and the disease progressed to a resolution of inflammation (Wallace, 2006). The drastric drop of COX-2 from treatment group shows intake of Cyclea barbata (miers.) extract induces resolution of inflammation, hence cutting inflammation time and induce faster healing process. The increased COX-2 in the tissue will convert arachidonic acid to prostaglandin (PGE2), and it will increase mitotic rate, a number of surfaces epithelial and mucosal foveolar cells, hence its mucus production and tissue mucosa layer thickness (Wallace, 2006).

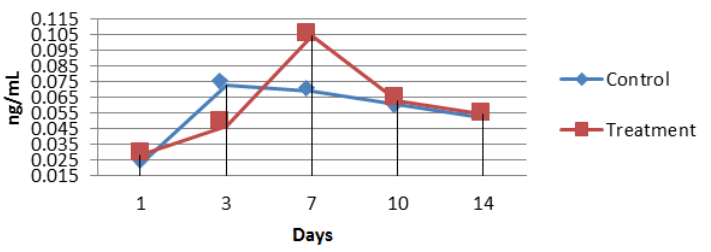

Figure 1. Graph of gastric tissue COX-2 concentration by time.

\section{SRF}

The role of SRF in mucosal healing comprise from hemostasis process by affecting megakaryocyte maturation hence controling platelet formation and function; inflammation prosess by inducing neutrophil migration; proliferation and glands reconstruction by activating immediate early genes and cytoskeletal genes, that in turn will trigger proliferation of smooth muscle cells and fibroblasts; differentiation of fibroblasts into myofibroblasts; pro-inflammatory regulators (e.g: interleukin- $1 \alpha$, interleukin-6, and COX-2); and angiogenic factor genes (i.e.: bFGF and vascular endothelial growth factor (VEGF)) (Tarnawski and Ahluwalia, 2012; Taylor et al., 2014).

SRF in treatment group consistently higher than control group since day 1 of treatment, and reaches its peak on day 14, indicating both groups were experiencing injury and undergo healing process and SRF is naturally increased in response to mucosal injury. After aspirin induction, gastropathy produced will cause tissue capiller haemorage, and blood serum leaked activated SRF. During inflammation process, growth factors, cytokines, and other mitogenic stimuli will further stimulate SRF production, consequently increasing SRF tissue level even higher as disease progress.

Tough COX-2 in control group reached peak concentration on day 3 , control group SRF in day 3 (K3) has not shown significant different with treatment group but linier to previous research that increase of SRF starting on day 3 (Tarnawski, 2012). On day 7, SRF in the treatment group is $20 \%$ higher compared to controlled showing SRF role in cellular repair and fibroblast formation needed for tissue repair (Chen, 2016). This proves though pathway is not cleared, Cyclea barbata (miers.) ethanol extract has effects to the molecular 
level. On day 14 control group, though there is a slight decrease, the level is still high showing on going healing process but in reduced pace. In treatment group however, the concentration increases meaning healing process continued. This will result in faster gland reconstruction, better ulcer healing quality and reducing the probability of gastropathy or re-bleeding in the same site (Arakawa et al., 2012; Kangwan, et al., (Figure 2).

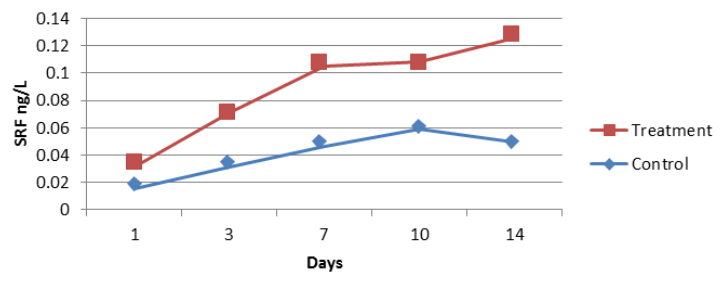

Figure 2. Graph of gastric tissue SRF concentration by time.

\section{CONCLUSION}

The increase of both COX-2 and SRF concentration shows Cyclea barbata (miers.) ethanol extract is useful in the treatment of NSAIDs gastropahty, specially aspirin induced gastropathy. Diseases progression was delayed on early days but then COX-2 was increased to a level where it triggers inflammation needed for healing but not excessive that causes chronic inflammatory diseases. It subsided starting on day 7 to promote resolution of inflammation and healing proven by SRF level constantly increasing as SRF needed to induce dedifferentiation, proliferation, and migration of cells. Hence it is concluded that Cyclea barbata (miers.) is a potent anti oxidant and an inflammation modulator.

\section{ACKNOWLEDGEMENTS}

The author would like to acknowledge the co-authors for the input and the University of Ciputra for funding the research.

\section{REFERENCES}

Alam MN., Faruk M., Chowdhury AI., Ahmed SS., Ahmad MF., et al., 2016. Comparative Study of Potential Anti-Cancerous and Cardio Protective Activities of Methanolic Leaf Extract of Cycleabarbata and Entadapursaetha. Res J Med Plant, 10(1), 113-119. http://doi.org/10.3923/rjmp.2016.113.11 9

Arakawa T., Watanabe T., Tanigawa T., Tominaga K., Fujiwara Y., Morimoto K. 2012. Quality of ulcer healing in gastrointestinal tract: Its pathophysiology and clinical relevance, 18(35), 4811-4822. http://doi.org/10.3748/wjg.v18.i35.4811

Brown TJ., Hooper L., Elliott RA., Payne K., Webb R., Roberts C., Symmons, D. 2006. A comparison of the cost-effectiveness of five strategies for the prevention of nonsteroidal anti-inflammatory drug-induced gastro-intestinal toxicity: a systematic review with economic modelling. Health Technology Assessment, 10(38), 202. http://doi.org/10.3310/hta10380

Chai J., Baatar D., Moon W., Tarnawski A. AS. 2004. Expression Of Serum Response Factor In Normal Rat Gastric Mucosa. Gastroenterology, 126, 1809-1818.

Chen P., Qin L., Li G., Tellides G., Simons M. 2016. Fibroblast growth factor (FGF) signaling regulates transforming growth factor beta (TGF $\beta$ ) - dependent smooth muscle cell phenotype modulation. Nature Publishing Group, (August), 1-11. http://doi.org/10.1038/srep33407

de Lira Mota KS., Dias GEN., Pinto MEF., Luiz-Ferreira Â., Monteiro Souza-Brito, AR., et al., 2009. Flavonoids with Gastroprotective Activity. Molecules 14, 979-1012

Farzaei MH., Abdollahi M., Rahimi R. 2015. Role of dietary polyphenols in the management of peptic ulcer. World Journal Gastroenterology, 21(21), 6499-6517. http://doi.org/10.3748/wjg.v21.i21.6499

Kangwan, N., Park, J-M., Hahm, KB. 2014. Quality of healing og gastric ulcers: natural products beyond acid suppresion. World J Gastroin Pathophysiology, 5(1), 4047. http://doi.org/10.4291/wjgp.v5140

Lucena PL., Cristina H-V, S., Pereira BF., de Cássia dSR., Barczyszyn WM., Aparecida RF., Akiko H-LC. 2015. Does the gastroprotective action of a medicinal plant ensure healing effects? An integrative study of the biological effects of Serjania marginata Casar. (Sapindaceae) in rats. J Ethnopharm, 172, 312-324. 
http://doi.org/10.1016/ j.jep.2015.06.025

Melcarne L., García-IP., Calvet, X. 2016. Management of NSAID-associated peptic ulcer disease. Expert Review of Gastroenterology \& Hepatology, 10(6), 723$733 . \quad$ http://doi.org/10.1586/ 17474124.2016.1142872

Muhammad SA. (2012). uji aktivitas antioksidan ekstrak dan fraksi daun cincau bijau rambat (Cyclea barbata Miers.) dan identifikasi golongan senyawa dari fraksi yang paling aktif. University of Indonesia.

Permanasari DA. 2015. Aktivitas elestrak etanol daun cincau bijau (Cyclea barbata Miers) sebagai penghambat pembentukan biofilm bakteri Salmonella typhi. University of Jember.

Ro S., Words K. 2016. Multi-phenotypic Role of Serum Response Factor in the Gastrointestinal System, 22(2), 193-200.

Tarnawski SA., Ahluwalia A. 2012. Molecular mechanisms of epithelial regeneration and neovascularization during healing of gastric and esophageal ulcers. Current Medicinal Chemistry, 19(1), 16-27. http://doi.org/10.2174/09298671280341 4088

Simon, J. P., Evan Prince, S., \& Prince, S. E. (2017). Natural remedies for non-steroidal anti-inflammatory drug-induced toxicity. Joumal of Applied Toxicology, 37(August 2016), http://doi.org/10.1002/jat.3391

Soylu A., Dolapcioglu C., Dolay K., Ciltas A., Yasar N., Kalayci M., Sever N. 2008. Endoscopic and histopathological evaluation of acute gastric injury in highdose acetaminophen and nonsteroidal anti-inflammatory drug ingestion with suicidal intent. World JGastroenterology, 14(43), 6704-6710. http://doi.org/ 10.3748/wjg. 14.6704

Tarnawski AS., Ahluwalia A., Jones, MK. 2012. The mechanisms of gastric mucosal injury: Focus on microvascular endothelium as a key target. Current Medicinal Chemistry, 19(1), 4-15. http://doi.org/10.2174/09298671280341 4079

Taylor A., Tang W., Bruscia EM., Zhang P-X., Lin A., Gaines P., Halene S. 2014. SRF is required for neutrophil migration in response to inflammation. Blood, 123(19), 3027-3036. http://doi.org/10.1182/ blood-2013-06

Trimurtini I. 2007. Efek anti ulkus ekstrak air daun cincau hijau (Cyclea barbata miers) terhadap mukosa dan kadar mukus gaster tikus jantan galur wistar yang diinduksi aspirin. Medika Kartika, 4(1), 1-15.

Verpoorte R., Beek VTA., Siwon H., Svendsen B. 1982. Studies on Indonesian medicinal plants VIII. 